Tropical Journal of Pharmaceutical Research October 2019; 18 (10): 2095-2100

ISSN: 1596-5996 (print); 1596-9827 (electronic)

(1) Pharmacotherapy Group, Faculty of Pharmacy, University of Benin, Benin City, 300001 Nigeria.

Available online at http://www.tjpr.org

Original Research Article

http://dx.doi.org/10.4314/tjpr.v18i10.14

\title{
Anti-diabetic potential of Plectranthus lanuginosus in streptozotocin-induced diabetic rats
}

\author{
Mohammed H Mukhtar ${ }^{1}$, Waleed H Almalki ${ }^{2}$, Muhammad Ahmed ${ }^{2 \star}$, Aisha \\ Azmat $^{3}$ \\ ${ }^{1}$ Department of Biochemistry, Faculty of Medicine, ${ }^{2}$ Department of Pharmacology, Faculty of Pharmacy, ${ }^{3}$ Department of \\ Physiology, Faculty of Medicine, Umm Al Qura University, Makkah, Saudi Arabia
}

*For correspondence: Email: hma00ahmed@hotmail.com; Tel: 00966-556618257

\begin{abstract}
Purpose: To determine the antidiabetic effect of methanol extract of Plectranthus lanuginosus leaves in streptozotocin-induced hyperglycemic (HGD) rats.

Methods: P. lanuginosus leaves were collected from Saad Medhas, Al Baha, Kingdom of Saudi Arabia. After defatting with $n$-hexane, they were extracted in vacuo at $40^{\circ} \mathrm{C}$ with $75 \%$ methanol. Streptozotocin $\left(50 \mathrm{mgkg}^{-1}\right.$, i.p.) was used to induce hyperglycemia (diabetes) in the rats. The HGD rats received either standard drug (glibenclamide, $10 \mathrm{mgkg}^{-1}$, p.o.) or Plectranthus lanuginosus leaf methanol leaf extract (PLLM) at doses of 200 and $400 \mathrm{mgkg}^{-1} /$ day, p.o. for 21 consecutive days. Blood samples were taken from the rat tails $2 \mathrm{~h}$ after dosing, and at 7-day intervals (i.e., 0, 7th, 14th and 21st days). The blood samples were used for measurement of fasting blood glucose (FBS), using a glucometer. On the 21st day, the rats were sacrificed via cardiac puncture. The activities of liver marker enzymes (SGPT and SGOT), and serum lipid profile (cholesterol, triglycerides, HDL and LDL) were determined using a hemolyzer.

Results: Streptozotocin treatment produced significant hyperglycemia in the rats $(348.9 \pm 5.6)$ when compared to control $(79.2 \pm 1.3)$. However, PLLM $\left(200\right.$ and $\left.400 \mathrm{mg} \mathrm{kg}^{-1}\right)$ produced significant and dose-dependent anti-diabetic (166.4 \pm 5.6 and $123.86 \pm 6.8$ respectively) and antihyperlipidemic effects in HGD rats, at levels similar to those produced by the standard drug, glibenclamide (120.6 \pm 6.4 ).

Conclusion: P. lanuginosus leaf extract possesses pronounced anti-diabetic and anti-hyperlipidemic properties which may be due to the presence of phenolic and flavonoid constituents in the plant. Therefore, the plant extract can be further developed for the management of diabetes.
\end{abstract}

Keywords: Plectranthus lanuginosus, Antidiabetic effect, Flavonoids, hyperglycemic (diabetic: HGD) rats

This is an Open Access article that uses a fund-ing model which does not charge readers or their institutions for access and distributed under the terms of the Creative Commons Attribution License (http://creativecommons.org/licenses/by/4.0) and the Budapest Open Access Initiative (http://www.budapestopenaccessinitiative.org/read), which permit unrestricted use, distribution, and reproduction in any medium, provided the original work is properly credited.

Tropical Journal of Pharmaceutical Research is indexed by Science Citation Index (SciSearch), Scopus, International Pharmaceutical Abstract, Chemical Abstracts, Embase, Index Copernicus, EBSCO, African Index Medicus, JournalSeek, Journal Citation Reports/Science Edition, Directory of Open Access Journals (DOAJ), African Journal Online, Bioline International, Open-J-Gate and Pharmacy Abstracts

\section{INTRODUCTION}

Diabetes mellitus (DM) is a metabolic ailment diagnosed as $\mathrm{FBS} \geq 7.0 \mathrm{mmolL}^{-1}(126 \mathrm{mg} / \mathrm{dL})$, random blood glucose $($ RBS $) \geq 11.1 \mathrm{mmol} / \mathrm{L}$
(200 $\left.\mathrm{mgdL}^{-1}\right)$, and glycated hemoglobin $\left(\mathrm{HbA}_{1 \mathrm{C}}\right)$ $\geq 48 \mathrm{mmol} / \mathrm{mol}$ ( $\geq 6.5 \mathrm{DCCT} \%) \quad[1]$. The incidence of DM is on the increase, and it has been estimated that by the year 2030, approximately 472 million people in the world 
may be affected by diabetes. The IDF 2011 report [2] indicates that Kuwait, Saudi Arabia, and Qatar are topmost countries with the preeminent percentages of DM in the Middle East and North Africa (MENA) region, with prevalence levels of 23,24 , and $23 \%$, respectively.

Recent pharmaceutical targets for DM management are focused on lifestyle (diet, exercise, weight loss), and use of appropriate medications. The current therapy for DM causes mild-to-severe undesirable side effects which could lead to death. Thus, attention is shifting steadily towards the folkloric system of medicinal plants for management of DM [3].

Many herbal plants and medicines have been studied for their antidiabetic and hypoglycemic effects. These plants include Tridax procumbens [4], Geigeria alata (G. alata) roots [5], Acacia nilotica pods [6]; Balanites aegyptiaca fruits, Guiera senegalensis leaves, Hyphaene thebaica epicarp and Trigonella foenum-graecum seeds [7]. Plectranthus lanuginosus grows in different parts of Kingdom of Saudi Arabia (KSA), especially in Al Baha. Different species of Plectranthus are already in use in folkloric medicine for treating disorders of the digestive system such as stomach pain, nausea, vomiting and diarrhea [8], as well as mouth and throat infections, gastritis and intestinal spasms [9]. There are no studies so far on the possible medicinal properties of Plectranthus. Therefore, this research was carried out to study the effect of Plectranthus lanuginosus on HGD rats.

\section{EXPERIMENTAL}

\section{Collection of plant material and extraction}

The whole plant material (comprising leaves and stem of Plectranthus lanuginosus) was collected in January 2014, from an area near Saad Medhas, Al Baha, KSA. The plant was kindly identified by Dr. Ibrahim Abd-Elhady, and a voucher specimen (no. = PLLMUQU786) was deposited at the Museum of Pharmacognosy Department, Faculty of Pharmacy, Umm Al-Qura University, Makkah-al-Mukarramah, Saudi Arabia.

Six hundred (600) grams of air-dried and powdered leaves and stems of plectranthus lanuginosus was defatted with $n$ - hexane $(2 \times$ $1.5 \mathrm{~L})$ and subjected to exhaustive extraction with aqueous methanol (75 \%; $3 \times 3 \mathrm{~L})$. The combined methanol extract was concentrated to dryness in vacuo at $40^{\circ} \mathrm{C}(47 \mathrm{~g})$ and code-named PLLM.

\section{Experimental animals}

In-bred 2-month-old Sprague Dawley (SD) rats of both sexes (weighing $220-260 \mathrm{~g}$ ) were used in the entire study. The rats were reared in the premises of the Faculty (Umm Al Qura University, Faculty of Pharmacy, Makkah, KSA) with fresh and balanced diet, and clean water was provided. Prior to STZ treatment, the rats were fasted overnight, but were permitted free access to clean drinking water. This study was executed according to the international regulations for the use of animals [10]. The experimental protocol was approved by the Animal Ethics Committee of Faculty of Medicine, Umm Al Qura University, Makkah, Saudi Arabia (ethical approval no. UQU-COP-EA\#14341).

\section{Oral acute toxicity study}

Oral toxicity test (acute) for PLLM was done using fresh and healthy rats (3 rats), following the Organization of Economic Cooperation and Development (OECD) Guideline 423. For this purpose, maximum limit dose of PLLM (2 g/kg) was administered orally using gavage. Noxious and toxic signs and/or mortality were recorded during the first $2 \mathrm{~h}$ after dosing. Then, the animals were monitored for the next $48 \mathrm{~h}$. Their body weights were recorded for 14 days. The extract was found safe at PLLM exposure levels up to a dose of $2 \mathrm{gkg}^{-1}$. Thus, PLLM doses of 200 and $400 \mathrm{mgkg}^{-1}$ were selected for use in subsequent studies on the antidiabetic effect of the extract.

\section{Anti-diabetic evaluation of PLLM}

Healthy male adult rats (200 $\pm 10 \mathrm{~g}$ body weight) were randomly selected. Thirty rats were divided equally into five groups as shown in Table 1.

\begin{tabular}{|c|c|c|}
\hline $\begin{array}{l}\text { Rat } \\
\text { group }\end{array}$ & Description & Treatment \\
\hline $\mathrm{I}$ & Normal control & Distilled water \\
\hline II & $\begin{array}{l}\text { HGD rats (positive } \\
\text { control) }\end{array}$ & Distilled water \\
\hline III & HGD rats & $\begin{array}{l}\text { Glibenclamide } \quad(10 \\
\left.\mathrm{mgkg}^{-1}\right)\end{array}$ \\
\hline IV & HGD rats & $\begin{array}{l}\text { PLLM }(200 \\
\left.\mathrm{mgkg}^{-1}\right)\end{array}$ \\
\hline V & HGD rats & $\begin{array}{l}\text { PLLM }(400 \\
\left.\mathrm{mgkg}^{-1}\right)\end{array}$ \\
\hline
\end{tabular}

Diabetes mellitus was induced in the rats using STZ (except group 1). For induction of DM, the rats were intra-peritoneally injected freshly prepared STZ solution in cold citrate buffer, $\mathrm{pH}$ 4.5 [11]. After 48 h, FBS levels were measured using a Bayer Contour Blood Glucose Meter 
(Germany), and rats with FBS $\geq 200 \mathrm{mg} / \mathrm{dL}$ were deemed diabetic [12]. The diabetic rats (groups III to V) were given PLLM extract or standard drug (glibenclamide) using oral gavage once a day for 21 consecutive days. Blood samples were taken through the tail tips at $2 \mathrm{~h}$ after dosing, and subsequently at 7-day intervals i.e. at $0,7^{\text {th }}, 14^{\text {th }}$, and $21^{\text {st }}$ days. Blood glucose level was determined in each sample with a glucometer [13]. On the $21^{\text {st }}$ day, $5-8 \mathrm{ml}$ blood sample was withdrawn directly from all experimental groups through cardiac puncture, and sera were separated [13]. The serum samples were used for estimation of various biochemical parameters, as indicated hereunder.

\section{Biochemical analyses}

Blood samples (obtained via cardiac puncture) were centrifuged at 3500 rpm for 15 mins. Liver function biomarkers: aspartate aminotransferase (SGOT) and serum glutamic pyruvic transaminase (SGPT); and lipid profile (triglycerides, total cholesterol, VLDL, and HDLcholesterol) were assayed using HumaLyzer 3000 .

\section{Statistical analysis}

Data are presented as mean \pm standard error means (SEM). For further interpretation, oneway analysis of variance (ANOVA) was done, followed by Tukey's multiple comparison tests, on Minitab 17.

\section{RESULTS}

\section{Oral acute toxicity}

The extract (PLLM) was non-toxic up to a dose of $2000 \mathrm{mg} \mathrm{kg}^{-1}$. For acute toxicity, the physical and emotional behaviors of the rats were continuously monitored for the first $2 \mathrm{~h}$, after which the rats were observed after $8 \mathrm{~h}$, and then every $8 \mathrm{~h}$ during the next $48 \mathrm{~h}$. The extract did not cause any significant changes in the animals' normal behavior, nor did it produce any mortality.

\section{Anti-diabetic effect of PLLM}

The results are presented in Table 2. The HGD rats (positive control: group II) exhibited a significant increase in FBS $(p<0.001)$ throughout the study period (21 days). The reference drug (glibenclamide, $10 \mathrm{mgkg}^{-1} / \mathrm{day}$ ) and PLLM (200 and $400 \mathrm{mgkg}^{-1} /$ day) produced significant and dose-dependent declines in FBS levels, relative to diabetic control rats on the $7^{\text {th }}, 14^{\text {th }}$ and $21^{\text {st }}$ days. A significant anti-diabetic effect was observed after 14 consecutive days of administration of glibenclamide and PLLM (200 and $400 \mathrm{mgkg}^{-1}$ ). Group IV (PLLM $400 \mathrm{mgkg}^{-1}$ ) showed noticeable improvement in diabetic status from the first week of the drug administration onwards (Table 2). With continuous treatment till the $21^{\text {st }}$ day, the high dose of PLLM (400 $\mathrm{mgkg}^{-1}$ ) and glibenclamide $\left(10 \mathrm{mgkg}^{-1}\right.$ ) reversed the STZ-induced hyperglycemia to normal levels, as shown in Table 2. As presented in Table 3, there were significant elevations in total cholesterol, LDL and triglycerides, and a significant decrease in HDL cholesterol in the HGD rats (group II), when compared with control (group I). However, continuous treatment with PLLM (groups III and IV) and glibenclamide (group V) for 21 days produced significant alterations in lipid levels $(p<$ 0.05). The SGPT and SGOT levels were also normal in PLLM- and glibenclamide-treated rats, but the diabetic control rats had significant elevations in the levels of SGPT and SGOT $(p<$ 0.001).

\section{DISCUSSION}

Diabetes mellitus (DM) is the fastest growing disorder in KSA [14], with heightened possibility of high level of mortality and huge medical expenditure [15]. Diabetes increases the risk of other disorders like cardiovascular disease, neuropathy, retinopathy and nephropathy, which are the most common complication of diabetes [16]. Thus, there is need for concerted research efforts to evolve effective therapy for the disease [17].

Table 2: Effect of PLLM on blood glucose levels in STZ-induced diabetic rats

\begin{tabular}{|c|c|c|c|c|}
\hline \multirow{2}{*}{ Treatment/group } & \multicolumn{4}{|c|}{ Fasting blood glucose level (mg/dL) } \\
\hline & O day & $7^{n} d a y$ & $14^{\text {th }}$ day & $21^{s t}$ day \\
\hline Control & $79.6 \pm 1.28$ & $75.28 \pm 1.0$ & $80.26 \pm 1.56$ & $79.21+1.3$ \\
\hline Diabetic control & $280.2 \pm 2.98^{\star *}$ & $298.19 \pm 6.15^{\star *}$ & $314.72 \pm 2.16^{\star *}$ & $348.89 \pm 5.6^{\star *}$ \\
\hline PLLM 200mgkg ${ }^{-1}$ & $278 . \overline{2} \pm 3.78$ & $246.6 \pm 1.29^{\star}$ & $236.3 \pm 3.83^{*}$ & $166.36 \pm 5.62^{*}$ \\
\hline PLLM 400mgkg $^{-1}$ & $270.9 \overline{3} \pm 1.67$ & $212.36 \pm 2.56^{*}$ & $199.6 \overline{3} \pm 2.4^{*}$ & $123.86 \pm 6.78^{*}$ \\
\hline $\begin{array}{l}\text { Glibenclamide } \\
\left(10 \mathrm{mgkg}^{-1}\right)\end{array}$ & $275.36 \pm 3.65$ & $238.62 \pm 3.38^{*}$ & $200.8 \pm 3.65^{*}$ & $120.56 \pm 6.36^{*}$ \\
\hline
\end{tabular}

Values are presented as mean + SEM $(\mathrm{n}=8) ;{ }^{*} p<0.01$, compared with HGD rats; ${ }^{\star *} p<0.01$, compared with control rats 
Table 3: Effect of PLLM on various biochemical parameters in HGD rats

\begin{tabular}{|c|c|c|c|c|c|c|}
\hline Treatment & $\begin{array}{c}\text { Cholesterol } \\
\left(\mathrm{mgdL}^{-1}\right)\end{array}$ & $\begin{array}{l}\text { Triglyceride } \\
\left(\mathrm{mgdL}^{-1}\right)\end{array}$ & $\begin{array}{c}\mathrm{HDL} \\
\left(\mathrm{mgdL}^{-1}\right)\end{array}$ & $\begin{array}{c}\mathrm{LDL} \\
\left(\mathrm{mgdL}^{-1}\right)\end{array}$ & $\begin{array}{l}\text { SGOT } \\
\left(I^{-1}\right)\end{array}$ & $\begin{array}{l}\text { SGPT } \\
\left(\text { IUL }^{-1}\right)\end{array}$ \\
\hline No & $69.5 \pm 1.08$ & $72.28 \pm 1.0$ & $26.08 \pm 1.12$ & $39.11 \pm 3.15$ & $75.25 \pm 3.24$ & $12.65 \pm 1.69$ \\
\hline Diabetic control & $115.6 \overline{2} \pm 0.98^{*}$ & $189.26 \pm 1.55^{*}$ & $17.65 \pm 1.26^{*}$ & $89.80 \pm 3.33^{*}$ & $119.89 \pm 5.65^{\star}$ & $56.91 \pm 6.20^{*}$ \\
\hline PLLM 200mgkg ${ }^{-7}$ & $68.31 \pm 0.88$ & $66.54 \underline{ \pm} 0.12$ & $26.5 \overline{6} \pm 0.38$ & $36.00 \pm 0.88$ & $63.51 \pm 3.72$ & $16.6 \overline{5} \pm 4.5$ \\
\hline PLLM 400mgkg & $65.1 \overline{ \pm} 0.44$ & $63.52 \pm 1.16$ & $28.54 \pm 0.81$ & $38.54 \pm 7.63$ & $65.29 \pm 4.38$ & $15.26 \pm 2.35$ \\
\hline$\left(10 \mathrm{mgkg}^{-1}\right)$ & $61.6 \pm 0.83$ & $78.29 \pm 0.37$ & $26.13 \pm 0.75$ & $28.65 \pm 3.6$ & $70.84 \pm 4.23$ & $18.10 \pm 5.22$ \\
\hline
\end{tabular}

Data are presented as mean \pm SEM $(n=8) ;{ }^{*} p<0.001$, compared with diabetic control rats

Alternative herbal medicines are used in different countries for DM, but most of these herbal remedies have not been scientifically investigated. It is necessary to study such medicinal plants because they might contribute to development of newer drugs/compounds for inclusion in the diabetologist's pharmacy.

Many species of Plectranthus are being used as alternative treatments for DM [18]. The antidiabetic effect of PLLM was assessed in the present study because the genus Plectranthus is a significant, prolific and extensively used genus in folkloric medicine in southern Africa [18].

In the current work, the two PLLM doses (200 and $400 \mathrm{mgkg}^{-1}$ ) exhibited significant and dosedependent blood glucose-lowering effects (antidiabetic activity) against STZ-induced DM in rats. This anti-diabetic response in PLLM-treated rats was similar to that produced with the standard drug glibenclamide. It is known that STZ produces hyperglycemia due to its cytotoxic effect on the beta cells of the pancreas [19]. However, in STZ-treated rats, PLLM significantly reduced the blood glucose level.

In earlier studies on Plectranthus amboinicus using a dose of $400 \mathrm{mgkg}^{-1}$, it was suggested that the significant anti-diabetic effects in rats might be due to individual or synergistic action of flavonoids and other bioactive phytoconstituents present in Plectranthus [18]. Another study also revealed the antidiabetic potential of Plectranthus esculenthus in STZinduced hyperglycemic rats [19]

In past studies, different extracts from different species of Plectranthus were reported to exert anti-diabetic effects against STZ- and alloxaninduced diabetes in different animal models. The findings in the current study on the anti-diabetic effect of PLLM (200 and $400 \mathrm{mgkg}^{-1}$ ) are in agreement with those reported in earlier studies. Plants that contain flavonoids, terpenoids, alkaloids, and glycosides possess antidiabetic and antioxidant potential. Flavonoids rejuvenate injured pancreatic beta cells, while saponins inhibit normal glucose transport by blocking the intestinal sodium-glucose co-transporter-1 (SGLUT-1) [20,21]. Earlier studies have reported the presence of tannins, flavonoids and saponins in Plectranthus [22]. Thus, the antidiabetic effect of PLLM might be due to existence of flavonoids and saponins in the extract.

Hypercholesterolemia and hyper-triglyceridemia are major complications of DM [23]. The significant fall in lipid profile (serum total cholesterol, triglycerides and LDL-cholesterol), while the concomitant increase in serum HDLcholesterol levels in the PLLM-treated diabetic rats, are strongly indicative of the antihyperlipidemic potential of PLLM. Research has revealed that phenolics have considerable antioxidant potential and, by inhibiting the activities of $\alpha$-glucosidase and $\alpha$-amylase, they downregulate carbohydrate metabolism [24]. Furthermore, polyphenols act on cardiovascular system in DM and rectify the metabolism of lipoproteins and lipids, eventually reversing hyperlipidemia [25]. The presence of phenolic constituents in Plectranthus could be one of the reasons for the higher anti-diabetic and antihyperlipidemic actions of this plant.

\section{CONCLUSION}

The results obtained in this study indicate that PLLM exhibits anti-diabetic effect against STZHGD in rats. It further ameliorates hyperlipidemia in diabetic rats. These effects may be due to its contents of flavonoids, saponins and phenolic compounds. Thus, the plant has potential for development as a potential phytomedicine for the cure of DM.

\section{DECLARATIONS}

\section{Acknowledgement}

The authors would like to thank the Institute of Scientific Research and Revival of Islamic Heritage for providing financial support through grant no.43310006, and Umm Al Qura University Makkah, KSA for their support during this research. 


\section{Conflict of interest}

No conflict of interest is associated with this study.

\section{Contribution of authors}

We declare that this work was done by the authors named in this article and all liabilities pertaining to claims relating to the content of this article will be borne by the authors. All listed authors read and approved the submission of manuscript for publication. The author also declares that that manuscript data, or part thereof has not been submitted to any other journal.

\section{Open Access}

This is an Open Access article that uses a funding model which does not charge readers or their institutions for access and distributed under the terms of the Creative Commons Attribution License (http://creativecommons.org/licenses/by/ 4.0) and the Budapest Open Access Initiative (http://www.budapestopenaccessinitiative.org/rea d), which permit unrestricted use, distribution, and reproduction in any medium, provided the original work is properly credited.

\section{REFERENCES}

1. American Diabetes Association. Diagnosis and classification of diabetes mellitus [published correction appears in Diabetes Care. 2010 Apr;33(4):e57]. Diabetes Care. 2010; 33 Suppl 1(Suppl 1):S62-S69. doi:10.2337/dc10-S062

2. Sherif S, Sumpio BE. Economic development and diabetes prevalence in MENA countries: Egypt and Saudi Arabia comparison. World J Diabetes 2015; 6(2): 304-311.

3. Parasuraman S, Kumar E, Kumar A, Emerson S. Free radical scavenging property and diuretic effect of triglize, a polyherbal formulation in experimental models. J Pharmacol Pharmacother. 2010; 1: 38-41.

4. Petchi RR, Parasuraman S, Vijaya C. Antidiabetic and antihyperlipidemic effects of an ethanolic extract of the whole plant of Tridax procumbens (Linn.) in streptozotocin-induced diabetic rats. JBCP 2013; 4(4): 88-92.

5. Hafizur RM, Babiker R, Yagi S, Chishti $S$, Kabir $N$, Choudhary MI. The antidiabetic effect of Geigeria alata is mediated by enhanced insulin secretion, modulation of $\beta$-cell function, and improvement of antioxidant activity in streptozotocin-induced diabetic rats. J Endocrinol, 2012; 214: 329-335

6. Ahmad M, Zaman F, Sharif T, Zabta MC. Antidiabetic and hypolipidemic effects of aqueous methanolic extract of
Acacia nilotica pods in alloxan-induced diabetic rabbits. Scand J Lab Anim Sci 2008; 35: 29-34

7. Gaber KE, Singhal U, Daowd O. Hypoglycemic and hypolipidaemic effects of some common plants extract in Type 2 diabetic patients at Eldabba area (North Sudan). IOSR J Pharm Biol Sci 2013; 8: 38-43

8. Hamill FA, Apio S, Mubiru NK, Bukenya-Ziraba R, Mosango M, Maganyi OW, Soejarto DD. Traditional herbal drugs of Southern Uganda (II). Literature analysis and antimicrobial assays. J Ethnopharmacol 2003; 84: 57-78.

9. Camara CC, Nascimento NR, Macedo-Filho CL, Almeida FB, Fonteles MC. Antispasmodic effect of the essential oil of Plectranthus barbatus and some major constituents on the guinea-pig ileum. Planta Med 2003; 69: 1080-1085

10. Kilkenny C, Browne WJ, Cuthill IC, Emerson M, Altman $D G$. Improving bioscience research reporting: the ARRIVE guidelines for reporting animal research. PLOS Biol 2010; 8: 1-7.

11. Rabbani SI, Devi K, Khanam S. Protective role of glibenclamide against nicotinamide-streptozotocin induced nuclear damage in diabetic Wistar rats. J Pharmacol Pharmacother. 2010; 1: 18-23.

12. Liu Z, Li J, Zeng Z, Liu M, Wang M. The antidiabetic effects of cysteinyl metformin, a newly synthesized agent, in alloxan- and streptozocin-induced diabetic rats. Chem Biol Interact. 2008; 173: 68-75.

13. Parasuraman S, Raveendran R, Kesavan R. Blood sample collection in small laboratory animals. $J$ Pharmacol Pharmacother. 2010; 1: 87-93.

14. Al-Nozha MM, Al-Maatouq MA, Al-Mazrou YY, Al-Harthi SS, Arafah MR, Khalil MZ, Khan NB, Al-Khadra A, AlMarzouki K, Nouh MS, Abdullah M, Attas O, Al-Shahid MS, Al-Mobeireek A, Diabetes mellitus in Saudi Arabia. Saudi Med J 2004; 25(11): 1603-1610

15. Alhowaish AK, Economic costs of diabetes in Saudi Arabia. JFCM 2013; 20(1): 1-7.

16. Sarwar N, Gao P, Seshasai SR, Gobin R, Kaptoge S, Di Angelantonio $E$, Ingelsson $E$, Lawlor $D A$, Selvin $E$, Stampfer M, Stehouwer CD, Lewington S, Pennells L, Thompson A, Sattar N, White IR, Ray KK, Danesh J. "Diabetes mellitus, fasting blood glucose concentration, and risk of vascular disease: A collaborative metaanalysis of 102 prospective studies". Lancet 2010; 375(9733): 2215-2222.

17. Vishwakarma SL, Rakesh S, Rajani M, Goyal RK. Evaluation of effect of aqueous extract of Enicostemma littorale Blume. In streptozotocin induced type 1 diabetic rats. Indian J Exp Biol 2010; 48: 26-30.

18. Eleazu CO, Eleazu KC, Chukwuma SC, Okoronkwo J, Emelike CU. Effect of livingstonepotato (Plectranthus esculenthus N.E.Br) on hyperglycemia, antioxidant activity and lipid metabolism of streptozotocin induced diabetic rats. Toxicol Rep 2014; 1: 674-681

19. Graham ML, Janecek JL, Kittredge JA, Hering BJ, Schuurman HJ. The streptozotocin-induced diabetic

Trop J Pharm Res, October 2019; 18(10):2099 
nude mouse model: Differences between animals from different sources. Comp Med. 2011; 61: 356-360.

20. Hakkim FL, Girija S, Kumar RS, Jalaluddeen MD. Effect of aqueous and ethanol extracts of Cassia auriculata $L$. flowers on diabetes using alloxan induced diabetic rats. Int J Diabetes Metab. 2007; 15: 100-106.

21. Tiwari AK, Rao JM. Diabetes mellitus and multiple therapeutic approaches of phytochemicals: Present status and future prospects. Curr Sci. 2002; 83: 30-38.

22. Asiimwe S, Borg-Karlsson AK, Azeem M, Mugisha KM, Namutebi A, Gakunga NJ. Chemical composition and Toxicological evaluation of the aqueous leaf extracts of Plectranthus amboinicus (Lour.) Spreng. Int. J. Pharm. Sci. Invent. 2014; 3: 19-27
23. Onunogbo C, Ohaeri OC, Eleazu CO, Eleazu KC. Chemical composition of mistletoe extract (Loranthus micranthus) and its effect on the protein, lipid metabolism and the antioxidant status of alloxan induced diabetic rats. J. Med. Res 2012; 1(4); 057-063

24. Iwai K. Anti-diabetic and antioxidant effects of polyphenols in brown alga Ecklonia stolonifera in genetically diabetic KK-A(y) mice. Plant Foods Hum. Nutr 2008; 63: 163-169

25. Zahra B, Parvin M, Fereidoun A. Dietary polyphenols as potential nutraceuticals in management of diabetes: a review J. Diab. Metab. Disord 2013; 12: 43-82 